\title{
THE NEMOCERA NOT A NATURAL GROUP OF DIPTERA.
}

\author{
By Frederick KNAB,
}

Bureau of Entomology.

The classification of the Diptera is based upon recognized evolutional principles. The forms in which the larva has a well developed head and the imago multi-articulate antennæ are placed lowest and from them are derived the higher flies, with the system of nerve-ganglia concentrated, headless larvæ and in the imago the number of antennal joints reduced and the venation specialized. Brauer, in his earlier attempts to formulate a natural classification of the Diptera on larval characters, gave primary importance to the reduction of the larval head. He considered phylogenetically lowest those forms in which there is a well developed head with the mouth-parts in normal position, and arranged the other families in sequence in accordance with the degree of reduction of the head, the relative concentration of the nerve centers and the modification of the mouth-organs. ${ }^{1}$ Later, when further study had revealed the existence of many refractory elements, he laid greater stress on the progressive concentration of the nervous system, and readjusted his classification with the help of this factor. ${ }^{2}$

Brauer's ideas have been generally accepted and our presentday classifications practically follow him. However, while the transition from the lower to the higher flies along the lines indicated by him may be readily followed in a general way, detailed study reveals many contradictions, more particularly anong the lower forms, within the so-called Nemocera. Very naturally these contradictions have led to various attempts toward a more natural grouping, none of which can be pronounced successful; the only ones worthy of mention in this connection are those of Osten Sacken ${ }^{3}$ and of Lameere ${ }^{4}$.

As already stated, the principles applied to the classification of the Diptera by Brauer are fundamental and must be accepted. But the presence of contradictory elements indicates that some fundamental factor has been overlooked, and such proves to be the case. This factor, more fundamental, as we shall see, than the reduction of the larval head, is the organization of the larval respiratory system. We have in dipterous larvæ several dis- 
tinct types of respiratory system. In certain families we find a series of lateral spiracles (peripneustic type), as in normal terrestrial insects. In others the larval tracheal system is laterally closed, open spiracles occurring only in single anterior and posterior pairs (amphipneustic), or in but a single posterior pair (metapneustic). Still other forms show a completely closed tracheal system (apneustic), the skin assuming a respiratory function, sometimes supplemented by specially evolved appendages (blood-gills).

It is evident that the presence of a series of open lateral spiracles represents the normal unmodified type and is therefore a more primitive condition, while the partial or completely closed respiratory system has been acquired in adaptation to an aquatic environment. We must therefore look upon the dipterous larvæ with lateral spiracles as an archaic type and any classification that disregards this fact must necessarily be faulty. From such an ancient type are to be derived the amphipneustic and metapneustic forms. As to the forms with wholly closed tracheæ, it must be pointed out that they may be derived equally well either from the modified types or directly from the peripneustic stock, and there is good evidence that such forms have originated in both ways.

While these conclusions have been reached by wholly independent reasoning, it must be pointed out that the phylogenetic significance of the modifications of the larval tracheal system has been already indicated many years ago. Palmén pointed it out in his classic work on the tracheal system of insects, but he left to others the application of the principle. ${ }^{5} \mathrm{He}$ argues that the functionless thread-like spiracular branches which exist in forms with wholly or partly closed tracheal system could not have been always functionless. "It is unthinkable that they were rudimentary from the beginning and have originated or been acquired phylogenetically as mere threads. On the contrary, they must have been formerly constituted like the other parts of the tracheal system and have had their full function in order to be able to occur now as rudimentary structures. The larvæ existing at present which possess a closed tracheal system, have therefore formerly had open stigmatal branches in all stages of their existence. This means, in other words: Out of the relatively primary, open form of tracheal system of the oldest insects, there has originated 
phylogenetically the relatively secondary, closed form existing among larvæ of the present time". (1. c., p. 72).

Strangely enough none of the attempts at the classification of the Diptera have taken this fundamental factor into consideration. While the condition of the larval respiratory system in the various families is stated in a perfunctory way in some classifications, its significance seems to have remained wholly unappreciated.*

Let us now survey the result of grouping the families of the so-called Nemocera according to the character of the larval tracheal system, first placing on the one side the forms with the primitive series of lateral spiracles and on the other the specialized forms with partially closed spiracles. Under the primitive peripneustic type we have the families Bibionidæ, Scatopsidæ, Mycetophilidæ, Sciaridæ, Chironomidæ (part) and Cecidomyidæ. The forms with partly closed tracheal system include the Psychodidæ, Culicidæ (part), Ptychopteridæ, Tipulidæ and Rhyphidæ. The apneustic forms do not, as one might expect, form a concrete natural group in culimination of the metapneustic type, but are of diverse origin.

Thus, in the Culicidæ the derivation of the apneustic Chaoborus larva is clearly indicated by the existence of a closely related, more primitive form (Eucorethra) with open posterior spiracles. On the other hand, we have in the larvæ of most of the Chironomidæ apneustic forms derived from peripneustic stock. This is demonstrated by the existence of peripneustic and apneustic larvæ in the closely related genera Ceratopogon and Culicoides. Where entire families have apneustic larvæ, as is the case with two within the family-complex here considered, their proper position must be decided by other evidences of relationship. With the two families in question, the Simuiidæ and the Blepharoceridæ, this evidence is so strong that they can be unhesitatingly associated with the peripneustic forms. In fact, in the larvæ of the Simuliidæ the series of lateral spiracles, although minute and not functional, may be still detected.

* Only Osten Sacken has felt, at least to a degree, the fundamental significance of differences in the respiratory system. He excluded Mycetobia pallipes from the Mycetophilidæ, on the ground that according to several good observers its larva is amphipneustic, while all other known forms are peripneustic (Proc. Ent. Soc. Phila., vol. 1 , p. $151 ; 1862)$. I have had no opportunity to examine this larva, but nevertheless believe that the supposed difference rests upon an error of observation. 
The adult characters of the groups thus created need not be discussed in detail at this time; suffice it to say that in this light also the groups give the impression of naturalness. But even their superficial consideration forces upon us another fact, and that is that we have in these groups two stocks which have become dissociated in the remote past and are developing along independent lines. For the evolutional picture presented by the adults is just the reverse of the larval one. The group with the more primitive (peripneustic) larvæ shows far the greatest specialization in the adults. This finds its most tangible expression in the reduction of the wing venation-its stronger development in the costal region together with a well developed costal vein, and a weakening of the posterior veins - as we see it.in the Scatopsidæ, Simuliidæ, Chironomidæ and Cecidomyidæ. In this last group this line of development reaches its culmination, not only in the greatly reduced wing veins, but also in the reduction of the number of tarsal joints (Heteropezinæ). In the larvæ, too, we find other evidences of extreme specialization along independent lines. As is well known, the larvæ of the Cecidomyidæ have no distinctly chitinized head, there having been a reduction, as in the higher flies; but the persistence of the lateral spiracles, as well as the adult characters, demonstrates the close relationship with the others of the series. Thus we can safely say that in the Cecidomyidæ we have the evolutionary apex of the peripneustic stock.

In the metapneustic series we find the adults exhibiting a far more primitive type. The wing-veins are more numerous, more evenly distributed over the wing-surface and all of nearly equal strength throughout. This condition alone makes it impossible to deduce the metapneustic forms from the existing peripneustic ones. They must have had their origin in peripneustic stock long since extinct, in which the adults likewise were still in an archaic state.

It is thus evident that the time-honored group of Nemocera must be discarded as an unnatural one. The multiarticulate antennæ of the imago, which have been relied upon as of primary value, and the phylogenetic significance of which in a broad way can not be ignored, must be discarded as a group character. The two groups here indicated may be designated by already established terms, originally applied in a much more limited sense, Oligoneura and Polyneura. This seems far pre- 
ferable to the creation of new terms, particularly as the definition of those groups has been modified by different workers and as the names are appropriately applicable to the present groups. The status of these groups is now as follows:

Oligoneura
Bibionidæ
Scatopsidæ
Simuliidæ
Mycetophilidæ
Sciaridæ
Blepharoceridæ
Chironomidæ
Cecidomyidæ

\author{
Polyneura \\ Psychodidæ \\ Culicidæ \\ Ptychopteridæ \\ Tipulidæ \\ Rhyphidæ \\ Orphnephilidæ
}

Postscript.- Since the foregoing was written, Dr. E. P. Felt has called my attention to the possibility of the occurrence of metapneustic larvæ among the Cecidomyidæ. The forms in question are the so-called resin gnats, recently referred by Kieffer to the genus Retinodiplosis, ${ }^{6}$ whose larvæ live in the resin exuding from the injured twigs of pines. Fortunately the larvæ of these forms have been studied and the necessary data were obtained, for Retinodiplosis resinicola $\mathrm{O}$. S. in papers by Comstock $^{7}$ and by Miss Eckel, ${ }^{8}$ and for $R$. resinicoloides Williams in a paper by this last author. ${ }^{9}$ The facts disclosed are highly interesting. These larvæ are structurally peripneustic, but functionally they are metapneustic. The lateral spiracles are minute and not functional, being under normal conditions embedded in the resin, while the last pair (on the eighth abdominal segment) is much enlarged and modified for its augmented duty.

The position of the Blepharoceridæ, as indicated in the foregoing, is confirmed through definite information regarding the organization of the larval tracheal system. No mention of larval spiracles could be found in the more recent literature on the group, and this led to the inference that none occur. In a recent paper Mr. Hugh Scott shows that in Paltostoma minute functionless spiracles occur on all six of the body segments of the larva ${ }^{10}$ and that such spiracles were already demonstrated on the larva of Curupira by Fritz Mueller in his classic paper. ${ }^{11}$ Therefore the Blepharoceridæ unquestionably belong in the peripneustic Series (Oligoneura). 


\section{Literature Cited.}

${ }^{1}$ Brauer, FrIEdrich-1869. Kurze Charakteristik der Dipteren-Larven zur Bekräftigung des neuen von Dr. Schiner entworfenen Dipteren-Systemes. Verh. zool.-bot. Ges. Wien, vol. 19, pp. 843-852.

2Brauer, Friedrich-1883. Systematische Studien auf Grundlage der DipterenLarven. Denkschr. mathem.-naturw. Classe kaisl. Akad. Wiss. (Wien), vol. 47 , pp. $1-100,5$ pls.

${ }^{3}$ Osten Sacken, C. R.-1892. On the characters of the three divisions of Diptera: Nemocera vera, Nemocera anomala and Eremochæta. Berlin. Ent. Zeitschr., vol. 37, pp. 417-466.

${ }^{4}$ Lameere, Aug.-1906. Notes pour la classification des Diptères. Mén. Soc. entom. Belg., vol. 12 , pp. 105-140.

'Palmen, J. A.-1877. Zur Morphologie des Tracheensystems. Helsingfors. 149, pp., 2 pls.

${ }^{6}$ Kieffer, J. J.-1913. Cecidomyidæ, in Wytsman, Genera Insectorum, 152 Fasc.

${ }^{7}$ Comstock, J. Henry-1880. Rept. Commissioner Agric. for 1879, p. 256.

${ }^{8}$ Eckel, LIDA S.-1903. The resin-gnat Diplosis and three of its parasites. Entom. News, vol. 14, pp. 279-284, pl.

${ }^{9}$ Williams, Francis X.-1910. The anatomy of the larva of Cecidomyia resinicoloides Williams. Ann. Ent. Soc. America, vol. 3, pp. 45-57, 3 pls.

${ }^{10}$ The early stages of Paltostoma schineri, Williston. Ann. Mag. Nat. Hist., ser. 8, vol. 15, pp. 181-202, pls. 9-11 (Febr., 1915).

${ }^{11} \mathrm{~A}$ metamorphose de um insecto diptero. Arch. Mus. Nac. Rio de Janeiro, vol. 4 , pp. 47-85, 147-151, pls. 4-7 (1881). 


\section{$2 \mathrm{BHL}$ Biodiversity Heritage Library}

Knab, F. 1915. "The Nemocera Not a Natural Group of Diptera." Annals of the Entomological Society of America 8, 93-99. https://doi.org/10.1093/aesa/8.1.93.

View This Item Online: https://www.biodiversitylibrary.org/item/43631

DOI: https://doi.org/10.1093/aesa/8.1.93

Permalink: https://www.biodiversitylibrary.org/partpdf/193760

\section{Holding Institution}

Smithsonian Libraries

\section{Sponsored by}

Smithsonian

\section{Copyright \& Reuse}

Copyright Status: NOT_IN_COPYRIGHT

This document was created from content at the Biodiversity Heritage Library, the world's largest open access digital library for biodiversity literature and archives. Visit BHL at https://www.biodiversitylibrary.org. 